\title{
PREREGISTRATION PUBLICITY IN AN EXCHANGE OFFER
}

As corporate acquisition by tender offer becomes increasingly popular, ${ }^{1}$ incumbent managements have sharpened their tactics to prevent a takeover. ${ }^{2}$ In some instances, their interference with an outsider's bid may be not only justified but also obligatory. ${ }^{3}$ A takeover poses an imminent threat to management-an outsider acquiring a majority of the target's stock will seldom be content as a mere investor but will replace the incumbent management. ${ }^{4}$ The resourcefulness of both acquiring corporations and hostile managements in carrying their fight to the shareholders has led to increased supervision by the Securities and Exchange Commission (SEC). In 1968, Congress enacted the William's Bill ${ }^{5}$ amending the Securities Exchange Act of 1934 (the 1934 Act) and providing a regulatory scheme of both disclosure and take-up mechanics for tender offers. But if the acquiring corporation offers its newly issued shares-instead of cash-in exchange for the target's shares, section 5 of the Securities Act of $1933^{6}$ is the principal provision insuring that the target's stockholders will have both the time and the accurate information necessary to make an informed decision. Section 5 (c) prohibits publications deemed offers to sell or buy securities before a registration statement is filed ${ }^{7}$ and,

1 The House report accompanying the Williams Bill noted that: "The increased use of cash tender offers to acquire control of corporations is evidenced by the fact that in 1966 there were over 100 such offers involving companies with securities listed on national securities exchanges as compared with eight in 1960." H.R. REP. No. 1711, 90th Cong., 2d Sess. 2 (1968).

2 Among the defensive tactics available to the management of the target company are: raising the annual dividend, splitting the stock, increasing the number of shares outstanding, purchasing stock, effecting an acquisition which would make the position subsequent to the tender offer contrary to antitrust laws, enacting restrictive charter provisions and bylaws, issuing a series of preferred stock, and merging defensively. Schmults \& Kelley, Cash Take-Over Bids-Defense Tactics, 23 Bus. LAw. 115 (1967); see Note, Defensive Tactics Employed by Incumbent Managements in Contesting Tender Offers, 21 Stan. L. REv. 1104 (1969).

3 See, e.g., Schmults \& Kelley, supra note 2, at 117-19. Although a takeover bid is arguably a matter solely between the offeror and the target's shareholders, management may believe that the best interest of their shareholders requires their critical evaluation of the offer and, if they see the offeror as a potential raider, they may have a fiduciary obligation to oppose the offer.

4 Cf. Fleischer \& Mundheim, Corporate Acquisition by Tender Offer, 115 U. PA. L. Rev. 317, 318 (1967).

5 Act of July 29, 1968, Pub. L. No. 90-439, 82 Stat. 454, anending Securities Exchange Act of $1934 \$ \$ 13-14,15$ U.S.C. $\$ \$ 78 \mathrm{~m}-\mathrm{n}$ (1964) (codified at 15 U.S.C. $\$ \$ 78 m-n$ (Supp. V, 1970)).

615 U.S.C. $\$ 77 \mathrm{e}(1964)$.

7 It shall be unlawful for any person, directly or indirectly, to make use of any means or instruments of transportation or communication in interstate commerce or of the mails to offer to sell or offer to buy through the use or medium of any prospectus or otherwise any security, unless a registration statement has been filed as to such security, or while the registration statement is the subject of a refusal order or stop order or (prior to the effective date of the registration statement) any public proceeding or examination under section $77 \mathrm{~h}$ of this title.

Id. $\$ 77 \mathrm{e}(\mathrm{c})$. 
in conjunction with section 8 (a) of the Act, $^{8}$ imposes a twenty-day deliberation period, after registration, before actual trading may begin. Certain specified information may be given by the offeror to the target's shareholders prior to filing under SEC rule $135,{ }^{9}$ promulgated under section 5 .

The section 5 (c) prohibition of preregistration announcements, however, may conflict with disclosure specifically required by section 13 (d) of the 1934 Act ${ }^{10}$ and generally mandated by rule $10 \mathrm{~b}-5^{11}$ as construed in SEC v. Texas Gulf Sulfur Co. ${ }^{12}$ In Chris-Craft Industries, Inc. v. Bangor Punta Corp. ${ }^{13}$ the Second Circuit recently considered the scope of permissible preregistration disclosure in the context of a stock for stock exchange offer. All four opinions in Chris-Craft recognized the difficulty of reconciling these seemingly inconsistent provisions, but none suggested a resolution which satisfactorily balances the policies of prohibiting publications before registration and providing an opportunity to evaluate a prospectus with those permitting or requiring certain information for the target's shareholders so that all investors enter the market with equal knowledge.

\section{Chris-Craft Industries, Inc. v. Bangor Punta Corp.}

As the first step in its plan to acquire Piper Aircraft Corporation (Piper), a leading manufacturer of light aircraft, Chris-Craft Industries, Incorporated (Chris-Craft), a diversified manufacturer of recreational products, began purchasing Piper shares on the open market in early January 1969 . On January 23, Chris-Craft published a cash tender offer for up to 300,000 shares of Piper stock at 65 dollars per share. This offer netted 34 percent of the 1,641,890 Piper common shares issued and outstanding. ${ }^{14}$ On February 27 , Chris-Craft filed with the SEC a registration statement and proposed prospectus for an exchange offer for an additional 300,000 shares. A second exchange offer was announced on May 7 and became effective on July $24 .^{15}$

8 Id. $\S 77 \mathrm{~h}(\mathrm{a})$.

817 C.F.R. $\$ 230.135$ (1970), quoted at text accompanying note 33 infra.

10 Section 13(d) of the 1934 Act requires any person who acquires equity securities and, after such acquisition is the owner of more than 10\% of that class of securities, if registered, to file a statement containing the identity of the persons for whom the shares were acquired, the source of the funds used in the acquisition, the purpose of the purchase, the number of shares beneficially owned, and information regarding any contracts, arrangements, or understandings with respect to the sharesin question. 15 U.S.C. $\$ 78 \mathrm{~m}$ (d) (Supp. V, 1970).

1117 C.F.R. $\$ 240.10 \mathrm{~b}-5$ (1970).

12401 F.2d 833 (2d Cir. 1968) (en banc), cert. denied, 394 U.S. 976 (1969).

13426 F.2d 569 (2d Cir. 1970) (en banc).

14 Id. at 571 .

15 Id. A "bit by bit approach" to acquisition has several advantages. It facilitates financing, requires a relatively small initial investment, puts pressure on the incumbent management which may induce it to cooperate, and decreases the number of shares that need to be acquired in the final bid for control. 
Piper's Board of Directors viewed with alarm these takeover attempts, advised their shareholders that the cash bid was inadequate, and began a series of defensive maneuvers attracting the scrutiny of the New York Stock Exchange, the SEC, and eventually the courts. ${ }^{16}$

While characterizing Chris-Craft's 65 dollar per share bid as "inadequate" in a letter to Piper shareholders, Piper management offered 300,000 authorized but unissued shares to Grumman Aircraft Engineering Corporation at the same price in an attempt to offset any success Chris-Craft might have gained. ${ }^{17}$ The Grumman sale was never completed, but Piper's announcement of the offer adversely affected Chris-Craft's initial offer. ${ }^{18}$

On March 22, Piper management issued 469,199 authorized but unissued shares to acquire control of United States Concrete Pipe Company of Florida and Southply, Incorporated and thereby make Piper less attractive to Chris-Craft. ${ }^{19}$ But Piper's failure to seek the approval of its shareholders or the New York Stock Exchange before issuing a significant bloc of shares, as its listing agreement required, led the Exchange to refuse Piper's listing application, suspend trading in Piper shares, and authorize delisting proceedings before the SEC. ${ }^{20}$ In response, Piper rescinded both acquisitions, and trading in Piper shares resumed.

Following this maneuver, the Piper family, which owned 31 percent of the outstanding shares, resumed negotiations begun early in January with Bangor Punta Corporation (Bangor Punta), a diversified manufacturer. ${ }^{21}$ Negotiations toward a defensive merger led to an agreement on May 8 under which the Piper family would exchange its 501,090 shares for certain Bangor Punta securities. ${ }^{22}$ Bangor

16 Chris-Craft Indus. Inc. v. Piper Aircraft Corp., 303 F. Supp. 191, 193 (S.D.N.Y. 1969), aff'd, 426 F.2d 569 (2d Cir. 1970) (en banc).

17 Increasing the number of shares outstanding decreases the fractional interest in Piper comprised by the shares Chris-Craft had acquired or could hope to acquire from the public. Thus a larger majority of the public would have to tender their shares in order for Chris-Craft to acquire control, and acquisition of control would become more expensive. See generally note 2 supra.

18303 F. Supp. at 193.

19 Chris-Craft's acquisition of United States Concrete Pipe Company of Florida through Piper would hardly further its intended expansion in the field of recreational vehicles. Its acquisition through Piper of Southply, Incorporated, a speedboat manufacturer, might violate antitrust laws.

20 The Exchange would normally give consideration to suspending or removing from the list a security of a company when:

15. Agreements are Violated-Company, its transfer agent or registrar, violates any of its, or their, listing or other agreements with the Exchange.

2 CCH N.Y. Stock Exch. Guide $\Uparrow 2499.20$ (1969).

$21 \mathrm{~A}$ frequent response of incumbent management to a cash take-over bid is to arrange a merger of the subject company with another corporation more to its like. Realistically this is not a defense tactic, but rather a form of orderly retreat, and one would expect that unless such a merger was being actively considered prior to the tender offer, it would be viewed by incumbent management only as a last, albeit very effective, resort.

Schmults \& Kelley, supra note 2, at 132.

22426 F.2d at 571. 
Punta also agreed to use its best efforts to acquire a majority of the outstanding shares and, in furtherance of this agreement, to offer " 'Bangor Punta securities and/or cash having a value, in the written opinion of The First Boston Corporation, of $\$ 80$ or more" " for each Piper share still outstanding. ${ }^{23}$ If Bangor Punta was successful in acquiring more than 50 percent of Piper's stock and, if on the opening day of the exchange offer the value of the shares offered to the family was less than 80 dollars, the compensation paid to the Piper family was to be increased by any difference between the value of the package offered the shareholders and 80 dollars per share. ${ }^{24}$

On May 8, the day after Chris-Craft's last exchange offer was announced, Piper and Bangor Punta issued identical press releases announcing their merger agreement. After stating that the Piper family would receive Bangor Punta securities for their shares, the release announced:

Bangor Punta has agreed to file a registration statement with the SEC covering a proposed exchange offer for any and all of the remaining outstanding shares of Piper Aircraft for a package of Bangor Punta securities to be valued in the judgment of The First Boston Corporation at not less than $\$ 80$ per Piper share. The registration statement covering all securities to be issued will be filed as soon as possible and a meeting of the shareholders of Bangor Punta Corporation will be called for approval. ${ }^{25}$

On May 26, alleging that the May 8 press release constituted an offer to sell securities before registration in violation of section 5 (c) of the 1933 Act, the SEC brought Piper and Bangor Punta before the District Court for the District of Columbia. Without admitting any of the allegations, both defendants consented to the entry of a

$23 I d$.

24 303 F. Supp. at 194. The Second Circuit was confused by and misstated this fact. 426 F.2d at 571 .

25426 F.2d at $571-72$. The release continued:

Mr. Piper said that in view of Bangor Punta's long-standing policy of maintaining autonomy in the management of its operating companies, and the similarity of operating philosophies between the two companies, he and the Piper family would strongly support the merger and would recommend it to all shareholders.

Mr. Wallace said Bangor Punta welcomed the association with Piper Aircraft, its world-wide distribution, and its prestigious product name. He said the consolidation would align the Piper Aircraft name with other leading Bangor Punta companies, including Smith \& Wesson, Starcraft Company, and Waukesha Motor Company.

Bangor Punta manufactures a wide variety of recreational vehicles including sailboats, houseboats, snowmobiles, campers, trailers and motor homes. A merger of Bangor Punta and Piper Aircraft would bring Bangor Punta into the light aircraft manufacturing business.

Sales of the combined companies would reach $\$ 450,000,000$ in fiscal 1969 , with approximately $\$ 180,000,000$, or $40 \%$, in the aircraft, recreational and leisure time fields.

Id. at 572 . 
permanent injunction barring them, inter alia, from issuing further releases of a similar nature before Bangor Punta's registration statement was filed. ${ }^{26}$

Bangor Punta filed its registration statement on May 29, included with its filing a copy of the May 8 agreement, and sent preliminary prospectuses to all Piper shareholders of record on the filing date. ${ }^{27}$ Its offer became effective on July 18 and expired July 29. Chris-Craft's second exchange offer expired six days later. Neither side had won a clear victory; Chris-Craft held 40 percent and Bangor Punta 44 percent of Piper's stock. ${ }^{28}$

Fearing that Bangor Punta's exchange offer, coupled with the Piper family agreement and private cash purchases, might give its opponent a majority and thus endanger its investment, ${ }^{29}$ Chris-Craft on July 22 sought a preliminary injunction requiring Bangor Punta to offer rescission to Piper shareholders who tendered in response to its exchange offer, to cease acquisition of further shares, to halt any merger plans, and to refrain from voting a bloc of 120,200 Piper shares acquired for cash between May 16 and 23. ${ }^{30}$ Chris-Craft based its request upon allegations that the press releases of May 8 violated section $5(\mathrm{c})$ of the 1933 Act and rule 135, and sections 9, 10(b), and $14(\mathrm{e})$ of the 1934 Act and the rules promulgated thereunder. ${ }^{31}$

District court Judge Tenney held that the press release merely announced that Bangor Punta had agreed to file a registration statement covering its forthcoming exchange offer and could not, on its face, be construed as an offer to sell securities within the meaning of section $5(\mathrm{c}) .^{32} \mathrm{He}$ found support for this interpretation in rule 135 , which provides in part that:

(a) For the purposes only of section 5 of the Act, the following notices sent by an issuer in accordance with the terms and conditions of this section shall not be deemed to offer any security for sale:

26 Id. at 572 .

$27303 \mathrm{~F}$. Supp, at 195.

28 Id. At the time the case came to argument on appeal, Chris-Craft held $46.2 \%$ of Piper's common stock, while Bangor Punta had acquired a majority with $52.7 \%$. 426 F.2d at 572 .

29 If Bangor Punta succeeded in obtaining a majority of Piper stock, Chris-Craft would lose not only the premium paid for tenders but also find it difficult to liquidate its investment quickly. Because Piper is a Pennsylvania company, a merger would require only a simple majority approval. PA. STAT. ANN. tit. 15, $\$ \$ 802,1902$ (1967), as antended, (Supp. 1970), and Chris-Craft might well be locked into a permanent minority position,

30303 F. Supp. at 192-93.

31 Id. at 196-97. This Comment deals solely with the allegation that the May 8 press release constituted a violation of $\S 5$ of the 1933 Act.

$32 I d$, at 196. 
(4) In the case of an exchange offering, the name of the issuer and the title of the securities to be surrendered in exchange for the securities to be offered, the basis upon which the exchange is proposed to be made and the period during which the exchange may be made, or any of the foregoing . . . . ${ }^{33}$

Judge Tenney construed the "basis upon which the exchange is proposed" phrase to immunize the press release references to the 80 dollar valuation. $\mathrm{He}$ concluded:

[T] he precise components which were to comprise the package of Bangor Punta securities to be offered for each share of Piper had not been determined at the time of the May 8th press release, [and] Bangor Punta and Piper could do no more than set forth the basis upon which the exchange offer was proposed in the same terms as contained in the May Sth agreement. ${ }^{34}$

This construction, he believed, was consistent with the New York Stock Exchange's guidelines for press releases, which prescribe that announcements "should be definite as to price, ratio, timing and/or any other pertinent information necessary to permit a reasonable evaluation of the matter." 35

Judge Tenney also found that after execution of the May 8 agreement, security against premature disclosure of the terms of the agreement could not be maintained. ${ }^{36}$ Because the 80 dollar figure was nearly 10 dollars above the market price for Piper shares at that time, ${ }^{37}$ those with knowledge of the forthcoming offer could trade with a substantial advantage over other investors. Thus Judge Tenney believed that the preregistration disclosure contained in the May 8 press releases was "both desirable and consonant with the directives of Securities \& Exch. Comm'n v. Texas Gulf Sulphur Co." 38 In sum,

3317 C.F.R. $\$ \$ 230.135(a),(c)(4)$ (1970) (emphasis added).

34303 F. Supp. at 196.

35

The extent of the disclosures will depend upon the stage of discussion, studies, or negoations [sic]. So far as possible, public statements should be definite as to price, ratio, timing and/or any other pertinent information necessary to permit a reasonable evaluation of the matter. As a minimum, they should include those disclosures made to "outsiders."

Id. (quoting New York Stock Exchange Company Manual at A-19 (July 19, 1968)) (emphasis supplied by court).

$36 \mathrm{Id}$. at 195. It is also possible that, as discussed below, text accompanying notes 71-72 supra, Bangor Punta was required to file a 13(d) statement. If so, institutional investors who scrutinize SEC files would be aware of the offer as well as "insiders" and "tippees." Unlike "insiders" and "tippees," investors whose insight stemmed only from public documents would be under no obligation to refrain from trading.

37 Wall St. J., May 8, 1969, at 36, col. 5.

38303 F. Supp. at 195. 
the district court found no violation of the securities laws by ChrisCraft's opponents in the struggle for control warranting a preliminary injunction. Chris-Craft then sought and received an expedited appeal to the Second Circuit.

In view of Bangor Punta's stipulation that no merger would be effected and a finding that no other irreparable harm would result if the injunction were denied, ${ }^{39}$ the Second Circuit sitting en banc ${ }^{40}$ affirmed the denial of the preliminary injunction. But the court of appeals took issue with the district court's treatment of section 5(c) and rule 135 and its interpretation of Texas Gulf Sulphur. Writing for the majority, Judge Waterman adopted the construction of the rule 135 exemption to section 5(c) suggested by Chris-Craft and by the SEC in its amicus curiae brief. ${ }^{41}$ The majority held that rule 135 presented an "exclusive checklist" of information not deemed an offer to sell securities before registration. The press release references to a package of Bangor Punta securities valued at not less than 80 dollars were viewed as falling outside the privileged categories. ${ }^{42}$ Judge Waterman also found the district court's reliance upon Texas Gulf Sulphur to be misplaced.

The only material fact in this case within the meaning of Texas Gulf Sulphur was Bangor Punta's commitment to offer its securities for Piper Aircraft shares. Rule 135 provides adequately for the announcement of a material fact such as this; further disclosure would . . . thwart other policies of the securities laws. ${ }^{43}$

The Second Circuit remanded the case for district court determination of the appropriate remedy in light of their finding of a section 5 (c) violation. In his concurring opinion, Judge Moore objected to this finding because he thought a finding on the merits should await

39 Speaking to the standard for judicial intervention in takeover contests, Judge Friendly stated:

[T] he participants on both sides act, not "in the peace of a quiet chamber," . . but under the stresses of the market place. They act quickly, sometimes impulsively, often in angry response to what they consider, whether rightly or wrongly, to be low blows by the other side. Probably there will no more be a perfect tender offer than a perfect trial. Congress intended to assure basic honesty and fair dealing, not to impose an unrealistic requirement of laboratory conditions .... These considerations bear on the kind of judgment to be applied in testing conduct-of both sides-and also on the issue of materiality.

Electronic Speciality Co. v. International Controls Corp., 409 F.2d 937, 948 (2d Cir. 1969).

40 In writing for the majority of the Second Circuit in its rehearing en banc, Judge Waterman substantially reiterated the opinion he wrote for the majority of a three-judge panel of the Second Circuit in the original hearing. See Chris-Craft Indus., Inc. v. Bangor Punta Corp., 69-70 CCH FED. SEC. L. REP. $\{92,510$ (2d Cir.), aff'd on rehearing, $426 \mathrm{~F} .2 \mathrm{~d} 569$ (2d Cir. 1970) (en banc).

41426 F.2d at 574.

$42 I d$.

43 Id. at 575 . 
trial in the district court. ${ }^{44} \mathrm{He}$ also disagreed with the majority's finding on the illegality of the press release, reading the offer to sell exemption of rule 135 as requiring the 80 dollar figure to be disclosed. Judge Anderson also concurred in the denial of the preliminary injunction, but agreed with Judge Lumbard's dissent that the proper balance between the seemingly conflicting statutory provisions should be struck in favor of permitting the preregistration information published on May 8. ${ }^{45}$ In short, the court divided because its construction in Texas Gulf Sulphur of the requirements of disclosure under section 10 (b) of the 1934 Act appeared to have so broadened that statute that at least two judges thought it no longer possible to comply with both section $10(\mathrm{~b})$ and the restrictions upon disclosure of preregistration information imposed by section 5(c) of the 1933 Act.

\section{Preregistration Disclosure: Exchange Offers}

\section{A. Section 5(c) and Rule 135: The Need for Consistency}

Section 5(c) of the 1933 Act provides that it is unlawful to: offer to sell or offer to buy through the use or medium of any prospectus or otherwise any security, unless a registration statement has been filed as to such security. ${ }^{46}$

Both the majority and dissent in Chris-Craft agreed that section 5(c) is designed to prevent the dissemination of information about a proposed purchase or sale of securities before the registration process has begun. ${ }^{47}$ "Offer" is broadly defined in section 2(3) of the 1933 Act 48 and construed to include publicity of a corporation's future plans especially if they include a forthcoming issue of new securities. ${ }^{49}$ But the prohibition of section $5(\mathrm{c})$ is not absolute; rule 135 exempts

44 Id. at $577-78$.

$45 \mathrm{Id}$. at $578-79$.

4615 U.S.C. $\$ 77 \mathrm{7}(\mathrm{c})$ (1964).

47 Under $\$ 5$ of the Securities Act of 1933 , no offers are permitted prior to registration. After filing of a registration statement but before its effective date, no sales are permitted, and written offers are permitted only in the form of a preliminary prospectus or of a "tombstone" advertisement. After the registration statement is effective, sales are permitted, and offers are restrained only by antifraud provisions. SEC Securities Act Release No. 4697 (May 28, 1964). In reference to the preregistration period, the release also provides that:

These principles, however, are not intended to restrict the normal communication between an issuer and its stockholders or the announcement to the public generally of information with respect to important business and financial developments. Such announcements are required in the listing agreements used by stock exchanges, and the Commission is sensitive to the importance of encouraging this type of communication. In recognition of this requirement of certain stock exchanges, the Commission adopted Rule 135, which permits a brief announcement of proposed rights offerings, proposed exchange offerings, and proposed offerings to employees as not constituting an offer of a security for the purposes of section 5 of the Act.

Id.; see 1 L. Loss, Securities Regulation 179-80 (1961).

48 See 15 U.S.C. \$77b(3) (1964).

40 SEC v. Arvida Corp., 169 F. Supp. 211 (S.D.N.Y. 1958). 
from the definition of offer as used in that section certain information concerning a proposed offering to the issuer's shareholders or the shareholders of another corporation. ${ }^{50}$ Even announcement of the specific information permitted by rule 135 is subject to certain time restraints, ${ }^{51}$ must state that the offering will be made only by means of a prospectus, ${ }^{52}$ and, in the case of an exchange offer, may include only "the name of the issuer and the title of the securities to be surrendered in exchange for the securities to be offered, [and] the basis upon which the exchange [of securities] is proposed to be made." 53 The timing of the May 8 release and the shadow it cast upon Chris-Craft's offer demonstrate how rule 135 might undercut section 5(c) and place an additional weapon, the early announcement of a rival exchange offer by a friendly corporation, into the arsenal of incumbent management.

When a corporation offers its newly issued securities to the public for cash, the statutory scheme envisioned by section $5(\mathrm{c})^{54}$ prevents those privy to unannounced corporate information as well as the uninformed public from trading until a registration statement is filed and becomes effective..$^{55}$ But when newly issued shares are offered in exchange for presently traded securities, section 5(c) cannot prevent either group from trading in target shares before the registration process is complete. Trading is not deferred but merely transferred from the unavailable to the freely traded securities. In the context of an exchange offer, target shares become rights to acquire the offeror's unissued securities. If trading in target shares is not to be halted whenever an exchange offer is planned, the most feasible solution is to permit announcement of the forthcoming offer but impose strict controls on the scope and kind of preregistration publicity, thereby affording all traders equal access to the relevant information. Insofar as rule 135 effectuates this solution by permitting distribution of basic information necessary to diminish the opportunity for unfair advantage to insiders and to quash inaccurate information, it furthers the statutory scheme of section 5 (c).$^{56}$ Insofar as it perpetuates the advantage of insiders or adds to uninformed trading, it is destructive of those ends.

Bangor Punta's press release unquestionably contained more in-

5017 C.F.R. $\$ 230.135$ (1970).

51 Although the point was not raised, Bangor Punta's May announcement preceded the effective date of the offer by 71 days and thus violated $\S(B)$ of rule 135 , 17 C.F.R. $\$ 230.135$ (b) (1970), which forbids notice to be given more than 60 days prior to the proposed date of the offering. The 60-day provision has since been deleted by the SEC. SEC Securities Act Release No. 5101 (Nov. 19, 1970).

5217 C.F.R. $\$ 230.135$ (c) (1970).

53 Id. $\$ 230.135$ (c) (4).

54 Note 47 supra.

55 See 15 U.S.C. $\$ 77 \mathrm{~h}$ (a) (1964) (how and when a registration statement becomes effective).

56 See note 47 supra. 
formation than could be sanctioned by the terms of rule 135,57 but Chris-Craft and the SEC challenged only "the most flagrant violation of section 5(c)," the 80 dollar valuation estimate. The defendants responded that the 80 dollar phrase was sanctioned by rule 135's reference to "the basis" of the exchange. ${ }^{58}$ Neither Chris-Craft nor the majority of the Second Circuit met this response head on, but rather contended that the disclosures permitted by rule 135 were "exclusive" and not an administrative attempt to list permissible disclosures which might be supplemented by a judicial rule of reason. ${ }^{59}$ Accepting the "exclusive checklist" argument and its policy justification that such an objective standard provides certainty for the financial community and the courts, neither of which was apparently challenged by the defendants, the majority held that Bangor Punta's 80 dollar value assessment was beyond the scope of preregistration information privileged under rule 135 . Without ever defining the "basis of the exchange" phrase, the court found the May 8 press release violative of section 5(c). Although admitting doubt as to the appropriate construction of the phrase, Judge Lumbard in dissent read the 80 dollar figure as permitted by this phrase and, more importantly, compelled by Texas Gulf Sulphur. ${ }^{60}$ Because the Second Circuit's disagreement on rule 135 runs much deeper than a semantic dispute, the rationale underlying the majority's narrow if not arbitrary construction and the dissent's uncertain but opposite result can best be understood in the context of the need recognized by the entire court for a consistent construction of section 5(c) and rule 135 .

In the exchange offer context, rule 135 typically comes into play when an acquiring company announces its intention to offer a new issue of its shares in exchange for those of the target company. When the shares about to be registered and offered are identical to the offeror's then widely traded and readily valued securities, rule 135 's "basis" phrase should allow disclosure of both the value of the offered shares and the specified exchange ratio. But the Bangor Punta preregistration announcement was far more complicated: the number and description of the securities to be included in the package were unknown, the judgment of the First Boston Corporation was to be substituted for the market evaluation mechanism, the characteristics of the securities in terms of potential risk and return were not disclosed, and most important, the 80 dollar value was not certain but merely a minimum valuation. ${ }^{61}$ If rule 135 permits this kind of preregistration announcement, a premium is put upon nonpublic information and trading in target shares on incomplete information is

57 See note 25 supra \& accompanying text.

58 Brief for Bangor Punta Corp., Appellee at 23-24, Chris-Craft Indus., Inc. v. Bangor Punta Corp., 69-70 CCH FEv. SEC. L. REP. If 92,510 (2d Cir. 1970).

50426 F.2d at 574.

60 Id. at $580-82$.

61 See text accompanying note 25 supra. 
encouraged. The majority of the Second Circuit recognized the danger such a broad interpretation of rule 135 posed for section 5 (c)'s statutory scheme. In light of this danger, the court apparently felt no obligation to discuss the defendant's "basis" arguments, but ruled in essence that whatever the "basis" phrase means, section 5(c)'s basic prohibitions against preregistration publicity must be preserved. Judge Waterman summarized this position:

We need not reach the question whether prudent investors would have [mis] construed the $\$ 80$ value or whether it would have been assumed, as was apparently the case, that the value referred to was based on such considerations as Bangor Punta's earnings and asset value as well as upon the sales price of the securities. It is enough to point out that under either construction the SEC had no way of checking the honesty of the figure, and that the public did not receive the detailed information it would have received from a prospectus issued after a registration statement had been filed. Such information would have eliminated the possibility, perhaps the probability, that some persons would have construed the $\$ 80$ figure as referring to the market value when that value was neither accurate nor intended. ${ }^{62}$

In spite of the court's failure to articulate its rationale, its holding is essential if section 5 (c) is to be effective in cases like Chris-Craft when there is a wide diversity in the information available to various investors which cannot be narrowed by a rule 135 announcement because publication of "the basis upon which the offer is proposed to be made" necessarily involves estimates of value and not simply a fixed exchange ratio. ${ }^{63}$ But regardless of the consistency this interpretation brings to section 5 (c) and rule 135 , competing considerations stemming from the 1934 Act's disclosure requirements may require the opposite conclusion suggested by Chief Judge Lumbard.

\section{B. Requirements of Disclosure Under Rule 10b-5 in the Context of an Exchange Offer}

Rule 10b-5 promulgated by the SEC under section $10(\mathrm{~b})$ of the 1934 Act provides:

It shall be unlawful for any person, directly or indirectly, by the use of any means or instrumentality of interstate commerce, or of the mails or of any facility of any national securities exchange,

(a) To employ any device, scheme, or artifice to defraud,

62426 F.2d at 575.

63 Judge Lumbard notes that in these circumstances the "basis" of the proposed exchange necessarily involves an estimate. Id. at 580 \& n.1. 
(b) To make any untrue statement of a material fact or to omit to state a material fact necessary in order to make the statements made, in the light of the circumstances under which they were made, not misleading, or

(c) To engage in any act, practice, or course of business which operates or would operate as a fraud or deceit upon any person,

in connection with the purchase or sale of any security. ${ }^{64}$

In Texas Gulf Sulphur, the Second Circuit construed rule 10b-5 broadly to require that those with inside information must either disclose it or, if they choose not to or are disabled from doing so by a corporate confidence, must refrain from trading. "Material" was interpreted to mean influential in the decisions of investors actually in the market. The phrase "in connection with" was construed to require only that the public be trading the securities on an exchange. ${ }^{65}$

In the instant case, Bangor Punta and Piper were not accused of failing to disclose all material information but precisely the opposite. After reaching agreement on May 8, the defendants had two options under Texas Gulf Sulphur: publish sufficient information to inform the public fully, or remain silent. ${ }^{68}$ The court ruled that, because on May 8 the defendants had not completed the details of their agreement so that it might be brought within rule 135's exclusive checklist, they could disclose only the fact of the offer without reference to the 80 dollar value minimum. This approach ignores the second optionremaining silent-an approach the $\mathrm{SEC}$ argued was dispositive of the case. Indeed the entire court assumed that Piper and Bangor Punta did not have the option to remain silent on May 8. Judge Lumbard gave two reasons for this assumption. First, the number of Piper and Bangor Punta employees with knowledge of the 80 dollar valuation had increased so that "[e]ven if under some legal or moral duty of restraint, a group this large could not be effectively policed or controlled." ${ }^{\text {or }}$ Second, if the defendants had not disclosed their agreement, including the price they agreed on for the proposed offering, Piper shareholders who tendered to Chris-Craft might, in both Judge Lumbard and Judge Anderson's view, have had a cause of action against Piper and Bangor Punta under rule $10 \mathrm{~b}-5{ }^{68}$ These reasons led both judges to conclude that regardless of the supervening restrictions of section 5(c) of the 1933 Act, anything less than the May 8 press release would not have fully disclosed information that met the

6417 C.F.R. $\$ 240.10 \mathrm{~b}-5$ (1970).

65401 F.2d at 860.

66 Brief for the SEC, Amicus Curiae at 21, Chris-Craft Indus., Inc. v. Bangor Punta Corp., 426 F.2d 569 (2d Cir. 1970) (en banc). See also 426 F.2d at 580-81.

67426 F.2d at 581.

$68 I d$. at $578-79,581$ n.3. 
investor-oriented test of materiality required by Texas Gulf Sulphur's construction of rule $10 \mathrm{~b}-5$.

The majority did not dispute the conclusion that Bangor Punta and Piper were compelled to disclose their May 8 agreement but, because of its desire to achieve consistency between rule 135 and section 5 (c), refused to find the 80 dollar figure material within the meaning of Texas Gulf Sulphur. Judge Waterman stated this reluctance:

Bangor Punta and Piper argue that even prior to the filing of a registration statement an immediate disclosure of market value is compelled in cases such as this both by SEC v. Texas Gulf Sulphur . . . and by the rules of the New York Stock Exchange. We do not agree. . . . Had Bangor Punta observed Rule 135 by revealing immediately its intention to make an exchange offer . . . adequate information concerning the proposed transaction would have been placed before the public ... ${ }^{69}$

\section{The Material Facts Doctrine and Section 13(d) of the 1934 Act}

Judge Lumbard both defined the test for determining which provision of the securities law controls and framed the issue dividing the court when he quoted the test of materiality set forth in Texas Gulf Sulphur: "whether the fact is one to which "[a] reasonable man would attach importance . . . in determining his choice of action in the transaction in question." " 70 If this standard is applied in the instant case, it is extremely difficult to avoid direct conflict with section 5(c) except by reading broadly the "basis" phrase of rule 135 , a solution already rejected. The assumption that a reasonable investor, although recognizing the ambiguities of the 80 dollar figure, would nonetheless find it significant in deciding whether to accept Chris-Craft's offer, is justifiable but leads to permitting publicity contrary to the policy of section $5(\mathrm{c})$.

All members of the court viewed the need for disclosure as resting upon the unfair advantage that knowledge of the 80 dollar figure was likely to give two groups of investors: insiders (persons either party to or involved in the Piper-Bangor Punta negotiations) and their tipees; and institutional investors scrutinizing information filed with the SEC under section 13(d) of the 1934 Act. Texas Gulf Sulphur limits the activities of the first group, but the presence of the second group injects a new element lying close to the center of the court's disagreement. Section $13(\mathrm{~d})$ requires that, when a person becomes

$69 \mathrm{Id}$. at 575 .

70 Id. at 580 (quoting SEC v. Texas Gulf Sulphur Co., 401 F.2d 833, 849 (2d Cir. 1968) (en banc), cert. denied, 394 U.S. 976 (1969)) (omissions by court in Chris-Craft). 
the beneficial owner of ten percent or more of any class of a corporation's stock, he must file a registration statement with the SEC disclosing certain information about the transaction. ${ }^{71}$ In its. 13(d) statement, Bangor Punta declared its agreement to acquire the Piper family's thirty percent holdings at 80 dollars per share conditioned upon an identical offer to the public. ${ }^{72}$ But when information about a forthcoming securities offering, the public disclosure of which is prohibited by section 5 (c), is incorporated in a section $13(\mathrm{~d})$ statement and thereby becomes public, trading in the target's shares (rights to acquire the unregistered securities) begins-precisely contrary to section 5(c). Because many plans for acquisition contemplate purchases of ten percent of the target's shares prior to an exchange offer, ${ }^{73}$ the section 13 (d) statement could readily be used to incorporate preregistration publicity in circumvention of section 5 (c). In fact, an acquiring corporation structuring the initial purchases to include a conditional public offering might use the Texas Gulf Sulphur holding to claim the right-indeed the legal compulsion-to publish this information immediately. In this situation, either the preregistration silence required by section 5 (c) or the principle of fairness underlying rule $10 \mathrm{~b}-5$ 's prohibition of insider trading must perforce be violated. This, in fact, is exactly where the Second Circuit left the matter. The majority achieved consistency between section 5 (c) and rule 135 only by discounting the risk of insider trading and trading by institutional investors ${ }^{74}$ in comparison to the danger of misleading large numbers of investors. Although Judge Lumbard would permit disclosure of the 80 dollar figure, he conceded that "[w] hen the securities to be offered are not specified at the time of the announcement, the investing public cannot even begin to make an independent evaluation of the offer and perforce may tend to react significantly but blindly to the unsupported dollar sum." ${ }^{75} \mathrm{He}$ further conceded that "there

7115 U.S.C. $\$ 78 \mathrm{~m}$ (d) (1) (Supp. V, 1970), discussed at note 10 supra.

72 The "Schedule 13D" filed by Bangor Punta stated, inter alia:

Bangor Punta has agreed, subject to shareholder and regulatory approval, with the [members of the Piper family] to make an exchange offer for approximately 501,000 shares of Piper Common Stock . . . .

$\therefore$ Bangor Punta has agreed to seek shareholder and regulatory approval to make a further exchange offer for any and all remaining Piper stock on the basis of cash and/or securrities having a value of at least $\$ 80$ per share. Such value to be determined by The First Boston Corporation.

Supplemental Brief of Bangor Punta Corp. \& David W. Wallace, Appellees, On Reargument, Addendum at 2-3, Chris-Craft Indus., Inc. v. Bangor Punta Corp., 426 F.2d 569 (2d Cir. 1970) (en banc) (emphasis supplied in brief).

73 See note 15 supra.

74 426 F.2d at 575-76. Chief Judge Lumbard noted:

The 13(d) (1) statement was placed in the public files of the Commission, a repository over which, it is not unreasonable to assume, the keener investment houses maintain a close scrutiny.

Id. at 581. Although such investors would probably be few in number, they have the ability, which they would certainly exercise in case of a major development, to purchase extremely large blocs of shares.

75 Id. at 580-81 (footnote omitted). 
is a possibility for abuse" 76 by corporate bootstrapping through the use of agreements structured to fall within section 13(d)'s requirements but beyond section 5(c)'s. However correct either the majority or dissent may be on the law, their result seems wholly unsatisfactory.

\section{The Need for Dual Standards}

When the majority accepted the relevance of Texas Gulf Sulphur and Judge Lumbard defined the issue in terms of that decision's formulation of "materiality" in rule $10 \mathrm{~b}-5$, the court foreclosed the most feasible solution to their dilemma. Texas Gulf Sulphur's definition of materiality arose in the absence of competing policies of nondisclosure under the 1933 Act. Although in most instances the standards for insider trading absent disclosure are identical with those for disclosure itself, no compelling reason dictates this rule if its application so tips the balance in favor of 1934 Act policies that those of the 1933 Act must be subservient. Nor is there a compelling reason why in the instant situation a corporation should not be required to make an admittedly qualified and limited public disclosure while at the same time its insiders are forbidden from trading. This approach, precisely the one taken by rule 135 , permits limited preregistration disclosure designed to remove most of the advantage of those with knowledge of the offer. Under a revised definition of materiality, the courts could articulate a rule of limited though mandatory disclosure to immunize the offeror or the target's management against suits by target shareholders who sold their shares without knowledge of a more favorable offer to come. A revision of the "materiality" doctrine for this purpose should have no impact upon the limited construction of the "basis thereof" phase in rule 135 suggested above, because rule 135 speaks to the limitation of disclosure only in the specific context of offers to buy or sell securities. Although the line drawn on such a standard might not differ radically from that actually drawn in Chris-Craft, recognition that the limitation need not be tied to the maximum limits of rule 135 , plus awareness that compliance with the minimum standards for corporate disclosure does not authorize insider trading, would permit the court to balance the securities laws' competing considerations.

Admittedly, the practical problems of policing insider trading become more difficult if Judge Lumbard's application of the Texas Gulf Sulphur test of materiality is not adopted in the context of announcements of forthcoming exchange offers. Perhaps the only feasible alternative is a flat prohibition against trading by the offeror, not only from the time the offer is announced as rule $10 \mathrm{~b}-6$ provides, ${ }^{77}$

76 Id. at 581.

77 Rule $10 \mathrm{~b}-6$ provides:

(a) It shall constitute a "manipulative or deceptive device or contrivance" 
but also from the time the offer is either agreed upon by offeror and target managements or authorized by the offeror's shareholders. ${ }^{78}$

Public disclosure of a proposed securities offering through the section 13 (d) statement is another matter entirely-one which should not be tolerated under any circumstances. Without reducing the present requirements of $13(\mathrm{~d})$, the SEC could promulgate rules limiting disclosure of such extraneous information from its files either absolutely or with the understanding that such information will not be used when trading in target shares. Alternatively, notice of the offering might be filed by the acquiring party as a supplement or amendment to the $13(\mathrm{~d})$ statement at the time the proposed offering is registered under section $5(\mathrm{c})$.

\section{CONCLUSION}

Due to their increasing frequency, and the increasing fierceness with which they are contested, exchange offers pose problems of growing importance and difficulty for effective securities regulation. The provisions enacted for the control of disclosure, although generally successful in other circumstances, appear insufficient and even selfcontradictory in this context. The source of this defect is also the key to its solution: the test of "materiality," which brings the various regulatory provisions into play, fails to distinguish adequately between situations in which its purpose and effect differ widely. The test of "materiality" determines what information, when in the possession of "insiders," bars them from trading in the securities concerned. Under another provision, "materiality" determines what information regarding preliminary negotiations must be disclosed. These cases are quite distinct, as are the questions to which they give rise. Failure to distinguish between them necessarily impairs the ability of the securities law to deal with them satisfactorily. Only when this is recognized can securities regulation hope to fulfill the purposes for which it was enacted.

as used in section 10(b) of the Act [of 1933] for any person,

(2) Who is the issuer...

by the use of any means or instrumentality of interstate commerce, or of the mails, or of any facility of any national securities exchange... to bid for or purchase for any account in which he has a beneficial interest, any security which is the subject of such distribution, or any security of the same class or series, or any right to purchase such security, ... . .

17 C.F.R. $\$ 240.10 \mathrm{~b}-6$ (1970) (emphasis added). The majority held that, after the May 8 announcement of Bangor Punta's offer, Piper shares became rights to acquire the new securities to be issued within the meaning of the rule. 426 F.2d at 577 . It also noted that the rise in the market price of Piper shares due to purchases by Bangor Punta might be interpreted by small investors as indicative of a favorable reaction to the Bangor Punta offer. Id.

78 Listing agreements with major securities exchanges and corporate charters, as well as the law of most states, makes stockholder approval a prerequisite to the issuance of new securities. 